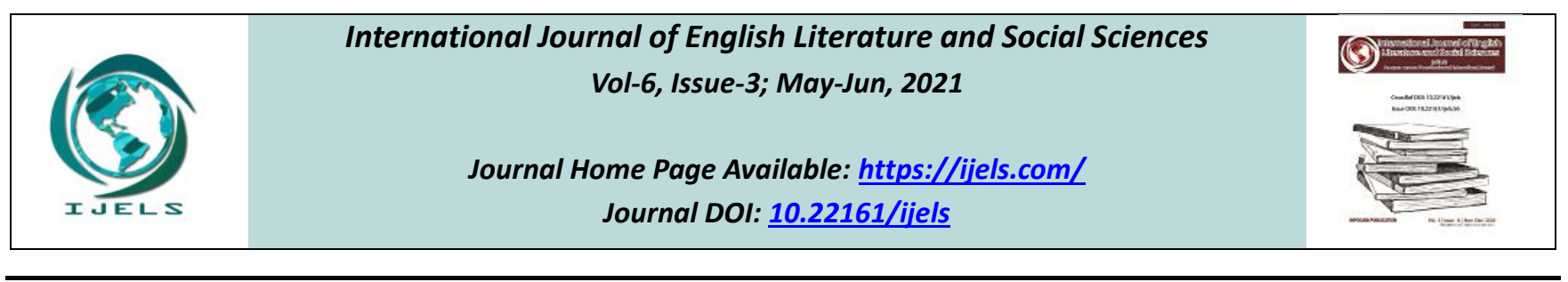

Peer-Reviewed Journal

\title{
Historicising Pinarayi Parappuram Communist Movement
}

\section{Babitha}

Research Scholar, Dept. of History, Kannur University, Kannur, Kerala, India

Received: 04 Mar 2021; Received in revised form: 16 Apr 2021; Accepted: 03 May 2021; Available online: 17 May 2021 (C2021 The Author(s). Published by Infogain Publication. This is an open access article under the CC BY license (https://creativecommons.org/licenses/by/4.0/).

\begin{abstract}
To examine the importance of Parappram Conference in the history of North Malabar and also discussed the growth and impact of Communist Party in Kerala Society and actual Importance of Pinaray Parappram Conference in the Political History of the North Malabar. The paper also tries to find out while the communist leaders select this place for the secret conference.
\end{abstract}

Keywords-Parapparam, Communist, Malabar.

The factors that led to the formation of the Communist Party in India were many. The great October Revolution in Russia was one among them , and at the time of that revolution India was a country getting prepared to wake up to struggle against imperialism . But it was a period when Marxism was little understood in India. A political activity or a movement based on Marxism sprang up in India only after 1921 and it cannot be even called a movement. Only certain Communist groups were functioning and certain young nationalists and trade union workers took the initiative in organizing these groups ${ }^{1}$. Communist groups also appeared in other large industrial centers. But actually, even before the Communist group in India, it was in Tashkent; in Russia that M.N.Roy organized a Communist organization called the Communist Party of India and Abani Mukherji played a prominent part in the activities of the Tashkent based Indian Communist organization. This was actually the initial period of the Indian Communist party ${ }^{2}$.

In Kerala a Communist party was officially formed only in 1939 though the trends towards such a move had started much earlier. By the time the Kerala unit of the Congress Socialist party took the decision to join the Communist party of India, Which had already becomes an all India organization by them. It had already becomes an all India organization by then. It had been declared illegal by the British Government and Communist party became a major political force in Kerala. It influenced all spheres of life. In a short span of time it created several movements and emerged as a powerful organization in Kerala .Its growth was the result of the continuous struggles. Its role in organizing peasants and workers movements in Kerala is also noted one and they provide a new impetus to the people of Kerala to fight against the caste system, social inequalities, janmi system, and imperialism. Land Reforms, health programmed, educational and social developments acquired by Kerala today is the result of the many struggles and sacrifices made by the Communist party. North Malabar is said to be the centre of revolutionary movements and there the most important historic event happened - parappuram Communist Conference. The parappuram conference officially decided to transform the state committee of Congress Socialist party in to the unit of the communist party India ${ }^{3}$.

By the second half of the $18^{\text {th }}$ century the traditional agrarian system of Malabar had undergone radical changes . These changes were not accidental but were the natural outcome of an age long process of evolution that were in operation in Malabar polity and economy. ${ }^{4}$ Agrarian system of Malabar trace its characteristic features connected with the political structure also. It had well established that monopoly class had enjoyed their absolute control over the means of production including political, judicial, military and even religious responsibility in their respective territorial jurisdiction in an agrarian society. Therefore, the social system itself had fused into an admixture of economic and political powers and such a situation had provided a matrix for the feudal mode of production and a localized structure of power. Agrarian serfdom and slave ownership were 
some of the peculiarities of this society. The agrarian system of particular society is gaining more importance in recent times, the result of social structure and changes in agrarian relation in North Malabar paved way for the awareness in rights and privileges and origin of Political consciousness 5 .

Pinarayi Parappuram Communist Party Conference, Which in turn recorded in the golden letters in the annals of Kerala history .In the 1920's and 30's when the spirit of national movement made its impact into this rural atmosphere, a total awakening was quiet newspapers and news about the freedom movement and echoes of certain political slogan accelerated this change .Local reading room also began to appear in different parts of Malabar. The initial lessons of political activism were made by making the reading room as the main centre of interaction. After the historic conference held at parappuram in 1939, where the state unit of the Communist Party India is formed, Communist methods were deeply filtrated into the minds of people and they began to work with enthusiasm. For the development of the party the new idioms and slogans then unknown to them ploughed their heart with a new human spirit ${ }^{6}$.

Pinarayi village in parappuram was selected for conducting the party conference because it was a strategically important place and since the village was an isolated area. Three sides were surrounded by river and there are no streets in the adjacent areas. It was decided to conduct meeting at Vivekananda vayanasala in the night. At the same time pinarayi and parappuram had a lot of followers of the communist ideology .But the members of the Congress Socialist Party and other people had no idea about this secret meeting .Besides to keep the secret nature of the conference and turned the attention from the parappuram another meeting was also conducted in the nearest place. It was the meeting of radical teachers union conducted at R.C.Amala U.P.School .The main organizer of this meeting was Pandyala Gopalan Master.

Twenty eight leaders acted as the leading participants in this conference; among prominent were E.M.S Nambuthiripad, P.Krishnapillai, K.Damodaran, P.Narayanan Nair, K.K. Varier, A.K. Goplan, .S. Namboothiri, E.P. Gopalan, V.V. Kunhambu, Chandroth Kunhi Raman Nair, Vadavathi Krishnan, and Pinarayi Krishnan Nair. Krishna Pillai for the first time disclosed to the delegates about the existence of the Kerala States Committee of the CPI composed of four people. He also told them that only the Communist Party having s correct policy that is, the policy of intensifying the struggle for freedom through direct action of the people during the time of war. A number of communist writers and some academic historians are unanimous about the change over the side of communist party by the Kerala CSP it was due to the failure of the Congress and the CSP to developed a correct attitude towards the struggle for freedom . K. Damodaran in 1955 said that communist party was the one party which asked for the mobilization of the entire masses against War and for the intensification of struggle for freedom by strikes, peasant struggle etc.

In this occasion it is also important to remember the contribution of Congress socialist party in Kerala Politics. They played a key role in the organization of peasant movement in Malabar. Along with they also helped in the formation of a union among workers. They propagated scientific socialist thoughts among the people through speeches, and magazines like Prabhatham and many other pamphlets. They inaugurated a cultural renaissance in Kerala. They also formed A Jeeval Sahithya Sangham at Kerala in 1937. The relation with Communist ideology led to the arrival of communist Party in Kerala. They realized the attitude of the Communist Party as true when the ideological conflict happened among Congress Party. Along the rise of Soviet Union also inspired them. Under these situations Congress Socialist Party members decided to join the Communist Party.

K.C George another important Communist leader who had joined the party during this time has written that the compelling issue for the CSP Man join CPI was the intensification of theoretical struggle within the CSP during the Second World War and he refused the CSP leader ship to mobilize the people against war .N.E Balaram had also stated that "The refusal of the CSP leader ship to mobilize the people against war was the main reason for this mass conversion to the CPI "7.Dr.K.K. $\mathrm{N}$ Kurup had accepted this view; the change over the Communist Party was mainly due to the Anti-war attitude to the leftist and the desire for the intensification of struggle against imperialism . In consequence Namboothiri Pad has given much broader reason then the above Embracing the Communist Party as early as 1936 .He could not claimed that the situation created in 1939 was the reason for the change over the Communist Party. He was stated the class character of the congress and CSP, were purely nationalistic stand point and consequently theoretical position attitude towards Soviet Union etc. were the reason for the change over ${ }^{8}$. That the secret Committee of four communists did bring over this change .In fact the situation created by the leader ship of the CPI in Kerala too affected the change over them got applause represents and made use it well

The question of making use of the opportunity created a war had been discussed long before the outbreak of war in 1938 and the Communist Party called it opportunist interpretation of Leninist slogan on war and 
opposed it. The Soviet Union during 1938 was still thinking about Anti fascist united front and was mainly concentrated on the peace initiatives. But after the HitlerStalin pact of August 1939, Soviet Policy changed and the communist party were encouraged to pursue the policy of Civil War and sabotage in their countries. Consequently the very slogan opposed previously was vociferously shouted by them a year later. If it is accepted that the CSP men's change over to the CPI was because of the commitment of freedom struggle and its intensification, Nambuthiripad who category has denied it has explicitly stated that both the INC and the CSP were nationalistic, whereas the CPI was internationalists. It was not the nationalistic, fervor that made the hard core CSP men accepted Communist views. Certainly some CSP men were unaware of the CPI manure. They may have been deceived by its new demagogy intensifying freedom movement during war. But the majority of the cadres who changed over to communism were hard core with a high degree of dogmatic commitment to the authoritarian CPI leader ship ${ }^{9}$. There is no cosence when Subrahmania shenoy died in 2006 November $14^{\text {th }}$, we lost the last link of the Parappram Conference. The meeting was presided over by K.P.R. Gopalan and the resolution was presented by P. Krishna Pillai. Only the communist party takes real step towards the fight against the imperialist powers and organizes the peasants from different parts of the country were tried to build unity and strong movements against imperialism the conference had selected the P. Krishna Pillai has the State Secretary and also the conference decided to form State Committee , District Committee and the lower party units immediately and decided to conduct more campaign for the formation of party cell ${ }^{10}$.In one cell it allowed only five members and it also accepted the guide lines the main responsibility of the cell is the following

1. To protect the party leaders

2. To observe the spy

3. To transfer the secret messages

The Cells were gathering at night, and smoking and the use of torch were forbidden. Each person should be liable to protect and secure the party. Thus the conference of the Communist Party at Parappuram had an important place. Parappuam conference of 1939 December. The Party had played a major role in the building of a new era in the history of Kerala. In Malabar 1940 September 15 a public strike was conducted against war. Under the leadership of CPI a strong agitation started in this time against War and the increasing of Price. Curphews was declared in about sixteen places in Malabar. In one of the firing, at Thalassery $\mathrm{Abu}$ and Chattukutty became martyr. In the Morzha incident, killing of a police inspector was charged on K.P.R. Gopalan and court was ordered to death sentence. Clash was taken place between people and police Mattannor and Kuthuparamba. The strikes also take place in different parts of the state like Kayyur, Karivellur, Kavumbay, Onchiyam, Thillangary, Punnapra Vayalar, etc are noted for the revolutionary vigor and new enthusiasm among the people.

CONCLUSION:

We may concluded that communist movement who pledged their lives to the dream of an egalitarian and a truly democratic society. Thousands of cadre were martyred on this path and many more continue to carry forward the dream and the fight in the face of state repression,violence, and infinite efforts at subversion. Through their self-effacing work, the communists have galvanised hundreds of millions of people into action in order to bring about far-reaching changes in society. They fought sectarian religious strife and caste discrimination, mobilized workers and peasants to fight to advance their rights, and oppressed sections of the people.The communist movement is aware that the exploitation of human beings and the establishment of a socialist society. Communist ideology and Communist movement have highly influenced the people in starting a Social Revolution in Kerala. Pinaray Parappram conference of the Communist Party was strong base were the party laid it foundation.

\section{REFERENCES}

[1] E. Balakrishnan, Communist Movement in Kerala, Kurukshethra Praskashan, 1998, P.1

[2] C. Balan, (ed) Reflections on Malabar: Society, Institution and Culture, Post Graduated Department of History Nehru Arts and Science College Kanhangad, 2000, P.129

[3] Souvenir, Pinarayi Parappuram Communist Movement p.38.

[4] M.T. Narayanan, Agrarian relation in late Medieval Malabar, Northern Book Centre, New Delhi, 2003. Page No, 165.

[5] K, Gopalan Kutty ,Malabar Padanangal (Mal), The State Institute of Language, Kerala Trivandrum ,PP.1-2

[6] Vikasana Rekha, Pinaray Gram Panchayat, 2006.pp.2-4

[7] E.Balakrishnan History of the Communist Movement in Kerala, Kururkshethra Pvt., Ltd, 1999, p.115

[8] Ibid; p.116

[9] Souvenir Communist Party Pinarayi-Parappuram Sammelanam Varshigakosham (Mal) 2005, pp, 34-37

[10] Ibid; P.38. 